Kralj, J., S. Barišić, V. Tutǐ̌, D. Ćiković, and H. Hoi. 2016. Habitat-dependent effect of a rare predator on apparent survival of male Black-headed Bunting. Avian Conservation and Ecology 11(1):9. http://dx.doi.org/10.5751/ACE-00849-110109

Copyright (C) 2016 by the author(s). Published here under license by the Resilience Alliance.

Research Paper

\title{
Habitat-dependent effect of a rare predator on apparent survival of male Black-headed Bunting
}

\author{
Jelena Kralj ${ }^{1}$, Sanja Barišić ${ }^{1}$, Vesna Tutiš ${ }^{1}$, Davor Ćiković ${ }^{1}$ and Herbert Hoi ${ }^{2}$ \\ ${ }^{1}$ Institute of Ornithology, Croatian Academy of Sciences and Arts, ${ }^{2}$ Konrad Lorenz Institute of Ethology (KLIVV)
}

\begin{abstract}
Both habitat changes and predation can cause population declines in farmland birds. Habitat changes may allow novel or invasive alien predators to establish populations in new environments, which can have major ecological consequences for native prey species. We studied effects of a novel avian predator, the Montagu's Harrier (Circus pygargus), on the survival of male Black-headed Buntings (Emberiza melanocephala). Between 2011 and 2015, survival of 35 territorial Black-headed Bunting males was monitored and their apparent survival in years with and without predators was computed. The apparent monthly survival (reported \pm SE) was very high during the breeding seasons when Montagu's Harrier was not present $(0.957 \pm 0.035)$ as well as in nonbreeding periods $(0.981$ $\pm 0.011)$. It was significantly lower during the breeding season of 2013 when Montagu's Harrier was present in the area (0.600 \pm 0.136$)$. Changes in habitat structure due to alteration in agricultural practice and temporal changes in weather conditions have presumably enabled Montagu's Harriers to breed in the study area and led to increases in the importance of birds in Montagu's Harrier's diet. The appearance of Montagu's Harriers in the study area strongly coincided with the steep decrease in the apparent survival of the male Black-headed Buntings. The lack of appropriate response in male Black-headed Buntings made them extremely vulnerable to attacks of this aerial predator.
\end{abstract}

\section{Effet lié à l'habitat d'un prédateur rare sur la survie apparente du Bruant mélanocéphale mâle}

RÉSUMÉ. Les modifications de l'habitat et la prédation peuvent tous deux être en cause dans les baisses de population d'oiseaux champêtres. Les modifications de l'habitat peuvent permettre à de nouveaux prédateurs ou des prédateurs étrangers envahissants d'établir des populations dans de nouveaux paysages, pouvant du coup entraîner des conséquences écologiques graves pour les espècesproie indigènes. Nous avons étudié les effets d'un nouveau prédateur aviaire, le Busard cendré (Circus pygargus), sur la survie des Bruants mélanocéphales (Emberiza melanocephala) mâles. Entre 2011 et 2015, la survie de 35 Bruants mélanocéphales mâles territoriaux a été suivie et leur survie apparente avec ou sans prédateurs a été calculée selon les années. La survie apparente mensuelle (rapportée \pm erreurtype) était très élevée au cours des saisons de nidification où le Busard cendré n'était pas présent $(0,957 \pm 0,035)$ ainsi qu'en dehors de la saison de reproduction $(0,981 \pm 0,011)$. Cette survie était très faible durant la saison de nidification de $2013(0,600 \pm 0,136)$ alors que le Busard cendré était présent dans le secteur. Les changements de la structure de l'habitat, attribuables aux modifications des pratiques agricoles, de même que les changements temporels des conditions météorologiques ont apparemment permis au Busard cendré de se reproduire dans l'aire d'étude et ont mené à l'augmentation de l'importance des oiseaux dans la diète du busard. L'apparition du Busard cendré dans l'aire d'étude a coïncidé grandement avec la diminution importante de la survie apparente des Bruants mélanocéphales mâles. Le manque de réactions appropriées de la part des bruants mâles les a rendus extrêmement vulnérables aux attaques de ce prédateur aérien.

Key Words: antipredator response; birds of prey; farmland birds; habitat change; population decline

\section{INTRODUCTION}

Habitat degradation and predation are often considered to be important causes for population declines in farmland birds. The loss of some habitat features such as hedgerows or wet meadows as well as declines in habitat quality, for example, changes in vegetation structure or pesticide application, affect the availability of food resources or the quality of nesting and foraging sites for birds (Fuller 2000). Predators may decrease prey population densities through direct consumption but can also have a nonlethal effect, through reducing individual fitness (Cresswell 2008). The effect of predation depends on the type of predator (avian, mammalian, etc.) and their hunting strategies. However, significant control of prey abundance through direct consumption is rarely confirmed (White 2013). The exceptions are alien predators that can have major ecological consequences even leading to the extinction of native prey species (Salo et al. 2007, McGeoch et al. 2010). In this context one might assume that the absence of shared evolutionary history between native organisms and new or "apparently new" predators may be an essential factor influencing the impact of such a predator on its prey.

The impact of habitat degradation and predation may vary independently or even be linked (Whittingham and Evans 2004). However, there are only a few studies that try to assess these interactions (Evans 2004). For example, intensive sheep grazing results in reduced cover for ground-nesting species, which in turn increases nest predation (Fuller and Gough 1999), while reduced 
Table 1. Mean spring (March-May) air temperature $\left({ }^{\circ} \mathrm{C}\right)$ and spring precipitation amount (mm) in Šibenik, Croatia for years $2011-$ 2015, percentiles of multiannual mean for the period 1961-1990, deviation from mean spring air temperature (in ${ }^{\circ} \mathrm{C}$ ), and precipitation amount (in percentage) compared to multiannual mean for the period 1961-1990, climate assessment categories according to percentile criterion (extremely cold/dry $<2$, very cold/dry 2-9, cold/dry 9-25, normal 25-75, warm/wet 75-91, very warm/wet 91-98, extremely warm/wet > 98; Juras 1995).

\begin{tabular}{|c|c|c|c|c|c|}
\hline Year & 2011 & 2012 & 2013 & 2014 & 2015 \\
\hline \multicolumn{6}{|l|}{ Temperature } \\
\hline Mean $/{ }^{\circ} \mathrm{C}$ & 15.2 & 14.9 & 14.6 & 14.7 & 14.8 \\
\hline Percentile & 94 & 90 & 83 & 85 & 88 \\
\hline Deviation $/{ }^{\circ} \mathrm{C}$ & 1.5 & 1.2 & 0.9 & 1.0 & 1.1 \\
\hline Category & very warm & warm & warm & warm & warm \\
\hline \multicolumn{6}{|l|}{ Precipitation } \\
\hline Amount/mm & 77.1 & 115.8 & 322.1 & 156.5 & 142.4 \\
\hline Percentile & 2 & 11 & 99 & 37 & 27 \\
\hline Deviation/\% & 43 & 64 & 178 & 87 & 79 \\
\hline Category & very dry & dry & extremely wet & normal & normal \\
\hline
\end{tabular}

food availability increases foraging distances and lowers parental nest defense (Evans 2004). Habitat change may also modify the distribution of predators and allow novel predators to enter and establish populations in new environments, bringing into contact predator and prey species that usually do not co-occur. Predation risk determines the spatial and temporal use of different habitat by prey species, creating the "landscape of fear" (Laundré et al. 2010). Proportions of safe and risky habitats in a landscape can affect abundance of prey species and relative impact of inter- and intraspecific relationships to prey population dynamics (Laundré et al 2014).

Here we studied the effect of the local predator, Montagu's Harrier Circus pygargus, on the survival of male Black-headed Buntings Emberiza melanocephala. The sexually dimorphic Black-headed Bunting is a long-distance migrant, breeding in southeastern Europe and wintering in western India. It is a common breeding species in Mediterranean rural habitats of Croatia. It spends only about three months on its breeding grounds, arriving in early May and departing in late July or early August. The Montagu's Harrier is a generalist predator with large variation in diet composition across its breeding range and with the highest prey diversity recorded in the southern part of its range (Terraube et al. 2011, Terraube and Arroyo 2011). Its most important prey are voles Arvicolinae (Arroyo and Garcia 2006) and small passerine birds, especially ground nesting species such as pipits Anthus, larks Alaudidae, and corn bunting Emberiza calandra (Underhill-Day 1993, Millon et al. 2002, Terraube and Arroyo 2011). The significance of birds in the diet of Montagu's Harrier is high in habitats with natural vegetation (grasslands and shrubs) and cereal-dominated agricultural areas, but much lower in agricultural areas with pastures (Terraube and Arroyo 2011).

The aims of this study were twofold: to determine the survival of male Black-headed Buntings during breeding and nonbreeding seasons, and to explore the possible effect of appearance of Montagu's Harriers on their breeding season survival. Montagu's Harriers appeared, as a novel predator, in a study area, apparently after weather-induced changes in habitat structure. Almost all territorial males in the study area could be individually identified and monitored on a daily basis, which resulted in extremely detailed knowledge of individual fates of a Black-headed Bunting population over several years.

\section{METHODS}

From 2011 to 2015, we studied the survival of 35 Black-headed Bunting males within an area of $2.9 \mathrm{~km}^{2}$, situated near the village of Dazlina in North Dalmatia, Croatia (4350' N, $15^{\circ} 43^{\prime} \mathrm{E}, 90$ $\mathrm{m}$ asl). The study plot has been chosen as one of the areas with the highest bunting population density, based on 40 onekilometer long transects surveyed by the authors in North Dalmatia during the breeding season of 2010. The study plot was covered by a Mediterranean rural mosaic of small patches of vineyards, olive groves, orchards, vegetable and cereal crops, meadows, and pastures, surrounded and intersected with maquis (dense evergreen shrubs). The climate is Mediterranean with hot and dry summers and mild and rainy winters. Based on the data from the Meteorological Station of Šibenik for the period of 1961-1990 (Meteorological and Hydrological Service 2015), mean spring (March-May) temperature was $13.7^{\circ} \mathrm{C}$ and mean spring precipitation $180.6 \mathrm{~mm}$. According to percentile ranks and classification ratings, spring months in 2011 and 2012 were classified as dry and very dry (Table 1 ). In contrast, spring months in 2013 have been described as extremely wet (99 percentile, i.e., expected to occur once in a century). As a consequence, in 2013 the short dry grass that normally covers the majority of pastures, meadows, olive groves, and fallow land was replaced by very tall and dense grass, while frequent rain prevented landowners from mowing. Precipitation in spring months in 2014 and 2015 was in a normal range.

Between 2011 and 2013 adult males were trapped upon arrival (in early May), using mist-nets and a playback lure. Birds were marked with a combination of three color-rings and a metal ring. The song of territorial males was recorded, which enabled individual recognition of males (Terry et al. 2005, Barišić 2015). Males that disappeared soon after marking were considered as nonterritorial males and omitted from the analysis. In total 30 territorial males were color-ringed and an additional five males were individually recognized by song spectrograms. In years 2011 -2013, from early May to mid- or late-July (depending on the year) between one and four researchers were present daily in the field, searching for marked birds and recording their behavior, e.g., song rate, territory use, pair interactions, interaction between neighboring males, etc. Strong territoriality and 
Table 2. Evaluation of Cormack-Jolly-Seber models for monthly survival of Black-headed Bunting (Emberiza melanocephala) males in 2011-2013. Models evaluated whether monthly survival rates $\phi$ varied with time ( $\mathrm{t}$ ), between breeding and nonbreeding season (s), and presence of Montagu's Harrier (Circus pygargus) in the study site (h) as well as whether resighting rates p were constant (c) or varied with time $(\mathrm{t})$. Models are ranked according to QAICc value.

\begin{tabular}{|c|c|c|c|c|c|c|}
\hline Model & QAICc & $\Delta \mathrm{QAICc}$ & $\begin{array}{c}\Delta \text { QAICc } \\
\text { Weight }\end{array}$ & Model Likelihood & No.Par & Qdeviance \\
\hline$\phi_{\mathrm{b}} p_{\mathrm{c}}$ & 45.49 & 0.00 & 0.898 & 1.000 & 4 & 6.61 \\
\hline$\phi_{\mathrm{t}} p_{\mathrm{c}}$ & 50.87 & 5.38 & 0.061 & 0.067 & 7 & 5.38 \\
\hline$\phi p$ & 52.09 & 6.61 & 0.033 & 0.037 & 3 & 15.35 \\
\hline$\phi_{\mathrm{b}} p_{\mathrm{t}}$ & 56.09 & 10.61 & 0.004 & 0.005 & 9 & 6.00 \\
\hline$\phi_{\mathrm{c}} p_{\mathrm{t}}$ & 57.66 & 12.16 & 0.002 & 0.002 & 7 & 12.16 \\
\hline$\phi p_{t}$ & 58.76 & 13.27 & 0.001 & 0.001 & 8 & 10.98 \\
\hline$\phi_{\mathrm{t}} p_{\mathrm{t}}$ & 60.24 & 14.75 & 0.001 & 0.001 & 11 & 5.38 \\
\hline$\phi p$ & 60.75 & 15.25 & 0.000 & 0.000 & 2 & 26.11 \\
\hline
\end{tabular}

conspicuousness of Black-headed Bunting males enabled us to easily record their presence, so all males were observed on almost a daily basis during the whole study period. In years 2014-2015 the surveillance of the study area was continued at a lower intensity: during two 14-days study periods, one at the beginning and the other at the end of the breeding season. We are confident that the two-week study periods were long enough to reliably observe all territorial males during the breeding season each year. In 2012 and 2013, each observation of raptor species was noted throughout the season. To ensure constant observation effort, only observations made by one researcher who was continuously present in the study area (SB) were taken into account.

The presence of marked buntings at the beginning of breeding season (before 11 May) and at the end of breeding season (present in the area at least until 30 June) was used to calculate the monthly apparent survival for the breeding (May-June) and the nonbreeding period (July-April) using program Mark (White and Burnham 1999). Modeling in Mark was performed for three cohorts (2011-2013) only on data collected between May 2011 and May 2014. July was included in the nonbreeding period because at that time males stop singing and join flocks that feed in the area. Cormack-Jolly-Seber (CJS) models (Lebreton et al. $1992)$ were built to estimate monthly survival rates $(\phi)$ and resighting probabilities $(p)$. The level of overdispersion $(\hat{c})$ of the global model $\left(\phi_{t} p_{t}\right)$ was $>1(\hat{c}=2.92)$, therefore, we used the program Release to test the goodness-of-fit and quasi-likelihood methods to derive QAICc (Anderson et al. 1994, Burnham and Anderson 2002). The analysis aimed to determine whether survival rates of male Black-headed Buntings differed before and after the appearance of the Montagu's Harrier.

\section{RESULTS}

The appearance of Montagu's Harrier in 2013 compared to other birds of prey was significantly higher in 2013 than in $2012\left(\chi^{2}=\right.$ $6.7, \mathrm{P}<0.01)$, while there were no similar changes in other raptor species $(\chi 2=0.4, P=0.54$, Fig. 1$)$.

Our models describe monthly survival rates and resighting probabilities for the Black-headed Bunting males (Table 2, Fig. 2). The most parsimonious model, the one with the lowest QAICc, included three survival parameters and confirmed that survival was influenced by the presence of harriers during the breeding season. All models estimated $p$ to be constant over time and equal
Fig. 1. Number of observations of Montagu's Harrier (Circus pygargus) and other raptors in the male Blackheaded Bunting (Emberiza melanocephala) survival study plot (Dazlina, North Dalmatia, Croatia) during May and June 2012 and 2013.

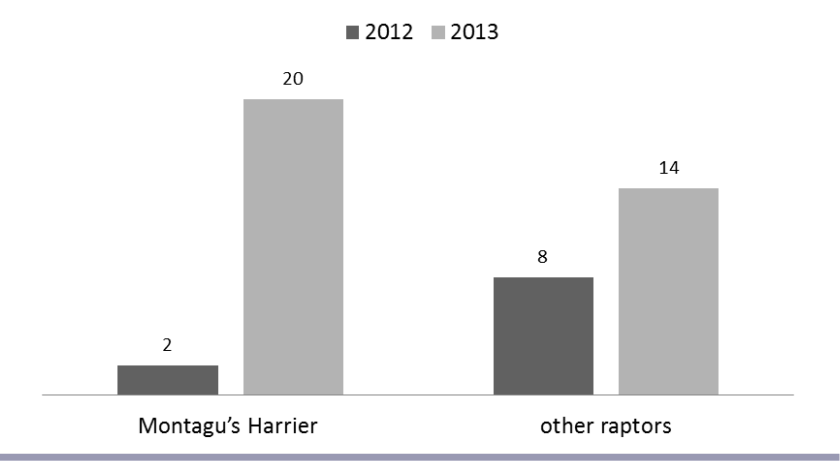

Fig. 2. Seasonal survival probabilities of Black-headed Bunting (Emberiza melanocephala) according to the general model $(\phi \mathrm{tpt})$ and the most parsimonious model $(\phi \mathrm{hpc})$. Seasons are given as breeding (br) and nonbreeding (nbr) periods, comprising two and ten months, respectively.

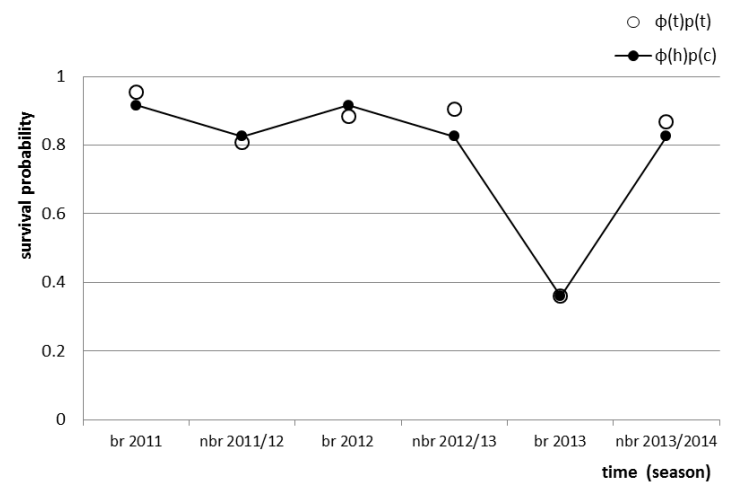


to 1 . Such a high resighting probability was the result of the high breeding-site fidelity and evident territoriality of males (using the same song-posts each year) as well as of the constant highobservation effort on the study area during the breeding season, which ensured that all males present in the study area were recorded. According to the most parsimonious model monthly survival was high during the breeding seasons when Montagu's Harrier was not present $(0.957, S E=0.035)$ as well as during the nonbreeding period $(0.981, S E=0.011)$, but dropped during the breeding season 2013 when Montagu's Harriers were present (0.600, $S E=0.136 ; \log$ rank test $\left.\chi^{2}=20.7, d f=1, p<0.001\right)$. The annual survival, calculated as the product of the breeding period survival $\left(\phi_{\mathrm{b}}{ }^{2}\right)$ and nonbreeding period survival $\left(\phi_{\mathrm{nb}}{ }^{10}\right)$, was 0.756 $(S E=0.036)$ in years without harriers present and only 0.297 in 2013 when harriers were present in the study area. Because our research was restricted to the single study area, apparent survival equals return rate. The decrease in the numbers of Black-headed Bunting males in 2013 was gradual and almost linear until early June, with the remaining males surviving until the end of the breeding season (Fig. 3). From birds that survived in 2013, six males returned to their breeding territories in 2014 (Fig. 4). Only one bird, marked in 2011 as an adult male, returned in 2015 and was therefore at that time at least six years old.

\section{DISCUSSION}

Male Black-headed Buntings' annual survival in years without Montagu's Harrier is remarkable because it represents the maximum values recorded for a medium-sized bird breeding either in a temperate or tropical region (Karr et al. 1990, Mouritsen 2003). For example, annual survival rates of adult British farmland birds based on ringing recoveries processed in the period from 1962 to 1995 ranged between 0.271 and 0.690 in stable populations, with males having higher survival rates than females in some species, whereas long-distance migrants had the annual survival rates below 0.4 (Siriwardena et al. 1998). This discrepancy could be the result of differences between long-term studies based on a large number of ring recoveries that tend to underestimate true survival (Elder 1985, Buckland and Baillie1987) and a very intensive study of a small color-ringed population that is based on resightings of territorial males only. Some studies based on capture-recapture methods also included birds marked on migration that did not stay in the study area more than a few days (Norman 1994), whereas they were omitted from our study. Nonetheless, the observed apparent survival during the nonbreeding season was much higher than in other migrants, where the likelihood that an adult male returns to the same breeding area is between 40-60\% (Mouritsen 2003). For example, intensive studies of color-ringed Willow Warblers Phylloscopus trochilus in England revealed average annual survival rates of 0.47 \pm 0.08 (Pratt and Peach 1991) and 0.35-0.44 (Lawn 1994) and return rates of $0.14-0.43$ (Lawn 1994), while return rate for the Great Reed Warbler Acrocephalus arundinaceus was 0.48 (Hansson et al. 2002).

The extreme difference in survival of the Black-headed Bunting males between the first two study years and the third year coincides with the shift in occurrence of Montagu's Harriers at the study plot. Although rarely present in the first two years, its frequency noticeably increased in 2013, when attacks on perching
Fig. 3. Changes in the number of territorial Blackheaded Bunting (Emberiza melanocephala) males in the study plot during May and June 2013.

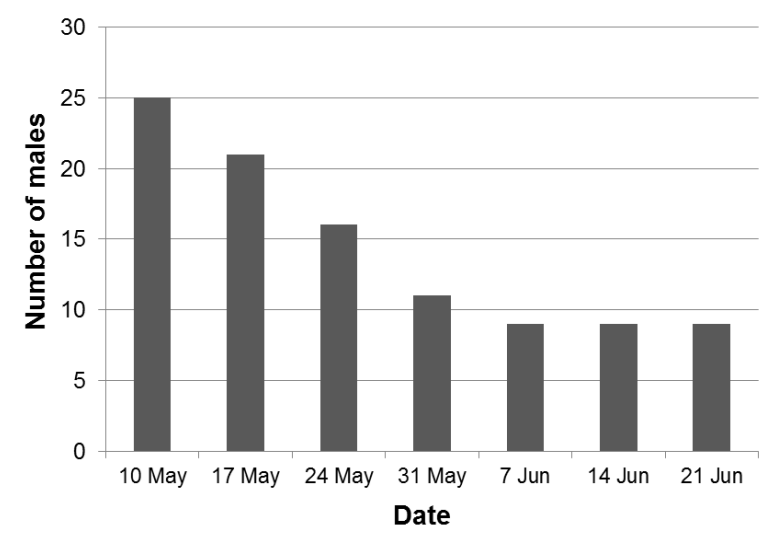

Fig. 4. Numbers of territorial Black-headed Bunting (Emberiza melanocephala) males in the study plot at the end of June in years 2011 to 2015. The marking and vocal identification of male Black-headed Buntings started in May 2011. Returning males are those observed in previous year(s).

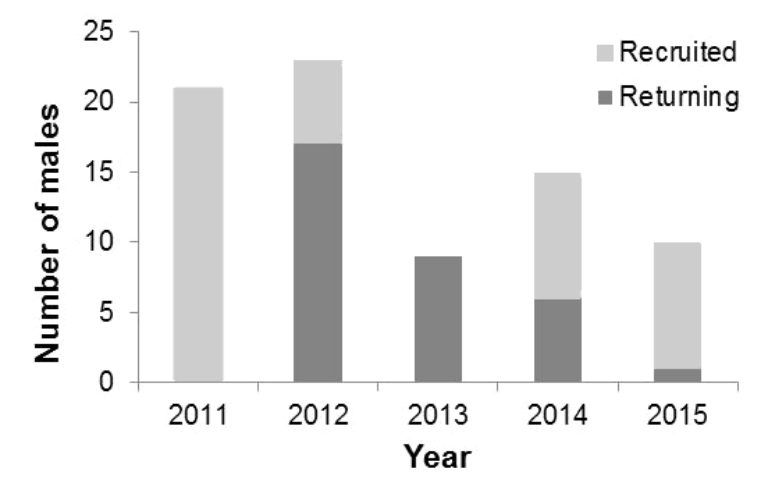

birds were observed on several occasions. Elevated levels of precipitation in 2013 changed the habitat from short or middle height to tall and dense grasslands. Furthermore, intensified abandonment of traditional agriculture in recent years provided favorable breeding opportunities for harriers. These changes in the habitat presumably influenced Montagu's Harrier's effect on Black-headed Buntings on two levels: it enabled harriers to breed in fields previously inaccessible to them as tall grass and absence of mowing provided a safe nesting site and it forced harriers to change their hunting technique.

In Northern Dalmatia, the Montagu's Harrier is a localized species, mostly breeding in spacious fields, covered predominantly with cereal crops or meadows (Tutiš et al. 2013), while the Blackheaded Bunting prefers a more closed habitat abundant with shrubs, vineyards, and olive groves. Therefore, these species in 
Croatia rarely share the same habitats albeit their ranges partly overlap. While foraging, harriers typically fly less than $3 \mathrm{~m}$ above the ground (Terraube et al. 2011), hunting small ground-living animals in areas with low or sparse vegetation (Cramp 1980). Voles and ground-nesting birds are probably important prey in open fields with cereal crops and meadows, which are the main breeding habitat of the Montagu's Harrier in Croatia. However, changes in habitat structure can influence prey selection of predators (Whittingham and Evans 2004) and the reduction in the availability of preferred prey may cause generalist predators to change their diets (Dunn 1997, Evans 2004). It is possible that tall and dense vegetation impaired Montagu's Harrier's ability to hunt voles and other ground-dwelling animals forcing them to change their typical foraging techniques and start hunting perched birds. Hence, Montagu's Harriers presumably represent not only a rather novel or unfamiliar predator to Black-headed Buntings, but also a predator that usually presents only a low predation threat.

Prey species evolved different strategies in response to predation risk, such as predator avoidance behavior, change of territory location, social protection (including flocking, vigilance behavior, and heterospecific sociality), choice of singing perches, and change in singing rate or loudness (Lima 2009). Different antipredator behavior of potential prey can influence the composition of a predator's diet (Terraube and Aroyo 2011), so the lack of adequate antipredator strategy in male Black-headed Buntings could have made this species a favorable prey. Brightly colored male buntings produce their song from the highest perches, thus being visually and acoustically prominent. In contrast, to avoid detection, similarly brightly colored Golden Orioles Oriolus oriolus hide in the vegetation and are almost invisible (Cramp and Perrins 1993). In our study plot, some songbirds such as Red-backed Shrike Lanius collurio reacted to the appearance of Montagu's Harrier by leaving their posts and hiding low in the bushes. Such behavior was not observed in male Black-headed Buntings, which frequently continued singing from the exposed perches. In general, birds using more exposed song posts are more susceptible to predation by an avian predator (Sparrowhawk Accipiter nisus) and sexually dichromatic species are depredated more frequently (Møller et al. 2006).

Although predator archetypes enable prey to recognize new, but taxonomically similar predators (Cox and Lima 2006), birds can distinguishing between raptors of high and low predation threat, showing adaptive, interspecific threat-sensitivity (Edelaar and Wright 2006). Adaptive responses to different predators might be either innate or learned (Griffin 2004) and the lack of an appropriate response of male Black-headed Buntings to the appearance of Montagu's Harriers is probably due to the fact that these two species rarely come into contact. The Montagu's Harrier is present at only $16.8 \%$ of global Black-headed Bunting breeding range, with the greatest overlap around Caucasus (calculations made based on projected IUCN species maps in ArcGis 9.3 ESRI 2009, BirdLife International and NatureServe 2014, 2015). However harriers are common on wintering areas of Blackheaded Bunting where birds represent an important part of their prey (Clark 1996). Therefore, it is likely that this case represents an example of a temporal naïveté. Black-headed Buntings gathered in winter flocks might have antipredator response for harriers, but during breeding seasons, high perched males are not common prey for Montagu's Harrier, and therefore assessed as low threat. Similar temporal difference in response to predator archetypes is known for migratory Artic-breeding birds that might encounter snakes at lower latitudes and recognize them as being dangerous, but in breeding seasons might lack appropriate nest defense behavior (Cox and Lima 2006). On the other hand, the Black-headed Bunting is a highly dimorphic, polygynous species with, for a passerine, extremely low levels of paternal care (Barišić 2015), all of which point to strong sexual selection in this species (Andersson 1994). In this sense delaying escaping may be a valid tactic for a Black-headed Bunting male whose fitness costs of fleeing the post and halting singing are high compared to other bird species in the study area.

When prey is not adapted to respond to hunting tactics of a new predator or even to recognize it as a threat, hunting efficiency of predators may dramatically increase and prey populations may suffer potentially devastating effects (Cruz et al. 2006, GomezMestre and Díaz-Paniagua 2011, Arribas et al. 2014). Predator species recovered because of management actions or reintroduction projects might affect local prey populations in a similar way as an alien predator. For instance, in Britain, reestablishment of the Eurasian Sparrowhawk caused the countrywide decline in House Sparrows Passer domesticus (Bell et al. 2010). Important aspect of Montagu's Harrier influence on the local Black-headed Bunting survival is that the effect extended into subsequent breeding seasons (2014 and 2015). Even though the observation effort was much lower in these two years, Montagu's Harriers were observed on a regular basis. In 2014 more than half of monitored bunting territories $(53.2 \%)$ remained empty while in 2015 even more territories (68.8\%) were unoccupied. Either new males settled on empty territories were soon depredated or the whole site was perceived unsuitable by Black-headed Buntings because of regular occurrence of harriers. In any case this points to an extended period needed for a prey species to get acquainted with an unfamiliar predator.

Other explanations for observed decreases in male survival apart from Montagu's Harrier predation are unlikely. We are not aware of a possible direct adverse effect of tall and dense grass on Blackheaded Bunting survival. Adult buntings feed mostly on grass seeds and regularly inhabit areas with tall grasslands and cereals during both the nonbreeding and breeding seasons (Cramp and Perrins 1994). Male Black-headed Buntings do not share parental duties with females, so their disappearance had no effect on the fledging success. After the disappearance of their mates, females continued to care for the broods without any evident change in the nest survival among years (Barišić 2015), which indirectly shows no increased mortality of females. Contrary to conspicuous males, females are secretive and usually keep lower in vegetation or on the ground. Besides, the drop in the population was particularly local and populations in other fields did not experience similar decline. For instance, the transect through the Ivinj valley (situated $7 \mathrm{~km}$ SSW from Dazlina) in 2010 revealed bunting's density of 33 pairs $/ \mathrm{km}^{2}$, while intensive study in 2014 resulted in 38 pairs $/ \mathrm{km}^{2}$ in the same area.

We conclude that the changes in habitat structure due to temporal changes in weather conditions have enabled Montagu's Harriers 
to breed in our study area and have increased the importance of birds in Montagu's Harrier's diet, causing the steep decrease in the apparent survival of the Black-headed Bunting males. Future study should focus on monitoring of further changes in the Blackheaded Bunting males' apparent survival and the rate of reoccupation of empty territories dependent on the presence or absence of the Montagu's Harrier. Given that Montagu's Harrier populations have increased in many parts of Europe (BirdLife International 2015), it might be interesting to see whether this "novel" predator may more generally benefit from facing naïve prey species and hence may affect other bird species as well.

Responses to this article can be read online at: http://www.ace-eco.org/issues/responses.php/849

\section{Acknowledgments:}

The study was partly funded by the Environmental Protection and Energy Efficiency Fund (EPEEF). We thank Rob Robinson, the Subject Editor, and anonymous referee for valuable suggestions that greatly improved an earlier version of the manuscript.

\section{LITERATURE CITED}

Anderson, D. R., K. P. Burnham, and G. C. White 1994. AIC model selection in overdispersed capture-recapture data. Ecology 75:1780-1793. http://dx.doi.org/10.2307/1939637

Andersson, M. 1994. Sexual selection. Monographs in behavior and ecology. Princenton University Press, Princenton, New Jersey, USA.

Arribas, R., C. Díaz-Paniagua, and I. Gomez-Mestre. 2014. Ecological consequences of amphibian larvae and their native and alien predators on the community structure of temporary ponds. Freshwater Biology 59:1996-2008. http://dx.doi. org/10.1111/fwb.12402

Arroyo, B. E., and J. T. Garcia. 2006. Diet composition influences annual breeding success of Montagu's Harriers Circus pygargus feeding on diverse prey. Bird Study 53:73-78. http://dx.doi. org/10.1080/00063650609461418

Barišić, S. 2015. Mating system, breeding biology and habitat selection of the Black-headed Bunting Emberiza melanocephala Scopoli (Aves). Thesis. University of Zagreb, Zagreb, Croatia

Bell, C. P, S. W. Baker, N. G. Parkes, M de L. Brooke, and D. E. Chamberlain. 2010. The role of the Eurasian Sparrowhawk (Accipiter nisus) in the decline of the House Sparrow (Passer domesticus) in Britain. Auk 127:411-420. http://dx.doi. org/10.1525/auk.2009.09108

BirdLife International. 2015. European Red List of birds. Office for Official Publications of the European Communities, Luxembourg.

BirdLife International and NatureServe. 2014. Bird species distribution maps of the world. Emberiza melanocephala. The
IUCN Red List of Threatened Species. Version 2015-3. BirdLife International, Cambridge, UK.

BirdLife International and NatureServe. 2015. Bird species distribution maps of the world. Circus pygargus. The IUCN Red List of Threatened Species. Version 2015-3. BirdLife International, Cambridge, UK.

Buckland, S. T., and S. R. Baillie. 1987. Estimating bird survival rates from organized mist-netting programs. Acta Ornithologica 23:89-100.

Burnham, K. P., and D. R. Anderson. 2002. Model selection and multi-model inference: a practical information-theoretic approach. Second edition. Springer, New York, New York, USA.

Clark, R. 1996. Preliminary observations on the importance of a large communal roost of wintering harriers in Gujarat (NW. India) and comparison with a roost in Senegal (W. Africa). Journal of The Bombay Natural History Society 93:44-50.

Cox, J. G., and S. L. Lima. 2006. Naiveté and an aquatic-terrestrial dichotomy in the effects of introduced predators. Trends in Ecology \& Evolution 21:674-680. http://dx.doi.org/10.1016/j. tree.2006.07.011

Cramp, S., editor. 1980. The birds of the Western Palearctic. Vol. II. Oxford University Press, Oxford, UK.

Cramp, S., and C. M. Perrins, editors. 1993. The birds of the Western Palearctic. Vol. VIII. Oxford University Press, Oxford, $\mathrm{UK}$.

Cramp, S., and C. M. Perrins, editors. 1994. The birds of the Western Palearctic. Vol. IX. Oxford University Press, Oxford, UK.

Cresswell, W. 2008. Non-lethal effects of predation in birds. Ibis 150:3-17. http://dx.doi.org/10.1111/j.1474-919X.2007.00793.x

Cruz, M. J., R. Rebelo, and E. G. Crespo. 2006. Effects of an introduced crayfish, Procambarus clarkii, on the distribution of south-western Iberian amphibians in their breeding habitats. Ecography 29:329-338. http://dx.doi.org/10.1111/j.2006.0906-7590.04333. $\mathrm{x}$

Dunn, E. 1977. Predation by weasels Mustela nivalis on breeding tits (Parus spp.) in relation to the density of tits and rodents. Journal of Animal Ecology 46:633-652. http://dx.doi. org/10.2307/3835

Edelaar, P., and J. Wright. 2006. Potential prey make excellent ornithologists: adaptive, flexible responses towards avian predation threat by Arabian Babblers Turdoides squamiceps living at a migratory hotspot. Ibis 148:664-671. http://dx.doi. org/10.1111/j.1474-919X.2006.00567.X

Elder, W. H. 1985. Survivorship in the tufted titmouse. Wilson Bulletin 97:517-524.

Environmental Systems Resource Institute (ESRI). 2009. ArcGis Desktop 9.3. ESRI, Redlands, California, USA.

Evans, K. L. 2004. The potential for interactions between predation and habitat change to cause population declines of farmland birds. Ibis 146:1-13. http://dx.doi.org/10.1111/ j.1474-919X.2004.00231.X 
Fuller, R. J. 2000. Relationships between recent changes in lowland British agriculture and farmland bird populations: an overview. Pages 5-16 in N. J. Aebischer, A. D. Evans, P. V. Grice, and J. A. Vickery, editors. Ecology and conservation of lowland farmland birds. British Ornithologists Union, Norwich, UK.

Fuller, R. J., and S. J. Gough. 1999. Changes in sheep numbers in Britain: implications for bird populations. Biological Conservation 91:73-89. http://dx.doi.org/10.1016/S0006-3207(99) 00039-7

Gomez-Mestre, I., and C. Díaz-Paniagua. 2011. Invasive predatory crayfish do not trigger inducible defenses in tadpoles. Proceedings of the Royal Society B 278:3364-3370. http://dx.doi. org/10.1098/rspb.2010.2762

Griffin, A. S. 2004. Social learning about predators: a review and prospectus. Learning \& Behaviour 32:131-140. http://dx.doi. org/10.3758/bf03196014

Hansson, B., S. Bensch, D. Hasselquist, and B. Nielsen. 2002. Restricted dispersal in a long-distance migrant bird with patchy distribution, the Great Reed Warbler. Oecologia 130:536-542. http://dx.doi.org/10.1007/s00442-001-0831-2

Juras, J. 1995. Metode za procjenu vremenske promjenljivosti kolièina oborina. Thesis. University of Zagreb, Zagreb, Croatia [Translated from the Croatian].

Karr, J. R, J. D. Nichols, M. K. Klimkiewicz, and J. D. Brawn. 1990. Survival rates of birds of tropical and temperate forests. Will the dogma survive? American Naturalist 136:277-291. http:// dx.doi.org/10.1086/285098

Laundré, J. W., L. Hernandez, P. López Medina, A. Campanella, J. López-Portillo, A. González-Romero, K. M. Grajales-Tam, A. M. Burke, P. Gronemeyer, and D. M. Browning. 2014. The landscape of fear: the missing link to understand top-down and bottom-up controls of prey abundance? Ecology 95:1141-1152. http://dx.doi.org/10.1890/13-1083.1

Laundré, J. W., L. Hernandez, and W. J. Ripple 2010. The landscape of fear: ecological implications of being afraid. Open Ecology Journal 3:1-7. http://dx.doi.org/10.2174/1874213001003030001

Lawn, M. R. 1994. Site fidelity and annual survival of territorial male Willow Warblers Phylloscopus trochilus at four adjacent sites in Surrey. Ringing \& Migration 15:1-7. http://dx.doi. org/10.1080/03078698.1994.9674065

Lebreton, J.-D., K. P. Burnham, J. Clobert, and D. R. Anderson. 1992. Modeling survival and testing biological hypotheses using marked animals: a unified approach with case studies. Ecological Monographs 62:67-118. http://dx.doi.org/10.2307/2937171

Lima, S. L. 2009. Predators and the breeding bird: behavioral and reproductive flexibility under the risk of predation. Biological Reviews 84:485-513. http://dx.doi.org/10.1111/j.1469-185X.2009.00085. $\mathrm{x}$

McGeoch, M. A., S. H. M. Butchart, D. Spear, E. Marais, E. J. Kleynhans, A. Symes, J. Chanson, and M. Hoffmann. 2010. Global indicators of biological invasion: species numbers, biodiversity impact and policy responses. Diversity and Distributions 16:95-108. http://dx.doi.org/10.1111/j.1472-4642.2009.00633. $\mathrm{X}$
Meteorological and Hydrological Service. 2015. Croatia. Meteorological and Hydrological Service, Zagreb, Croatia. [online] URL: http://klima.hr/ocjene_arhiva_e.php

Millon, A., J.-L. Bourrioux, C. Riols, and V. Bretagnolle. 2002. Comparative breeding biology of Hen Harrier and Montagu's Harrier: an 8-year study in north-eastern France. Ibis 144:94-105. http://dx.doi.org/10.1046/j.0019-1019.2001.00009.x

Møller, A. P., J. T. Nielsen, and L. Z. Garamszegi. 2006. Song post exposure, song features, and predation risk. Behavioral Ecolology 17:155-163. http://dx.doi.org/10.1093/beheco/arj010

Mouritsen, H. 2003. Spatiotemporal orientation strategies of long-distance migrants. Pages 493-513 in P. Berthold, E. Gwinner, and E. Sonnenschein, editors. Avian migration. Springer, Berlin, Germany. http://dx.doi.org/10.1007/978-3-662-05957-9_34

Norman, D. 1994. The return rate of adult male Wood Warblers Phylloscopus sibilatrix to a peripheral breeding area. Ringing \& Migration 15:79-83. http://dx.doi.org/10.1080/03078698.1994.9674077

Pratt, A., and W. Peach. 1991. Site tenacity and annual survival of Willow Warbler Phylloscopus trochilus population in Southern England. Ringing \& Migration 12:128-134. http://dx.doi. org/10.1080/03078698.1991.9674005

Salo, P., E. Korpimäki, P. B. Banks, M. Nordström, and C. R. Dickman. 2007. Alien predators are more dangerous than native predators to prey populations. Proceedings of the Royal Society B 274:1237-1243. http://dx.doi.org/10.1098/rspb.2006.0444

Siriwardena, G. M., S. R. Baillie, and J. D. Wilson. 1998. Variation in the survival rates of some British passerines with respect to their population trends on farmland. Bird Study 45:276-292. http://dx.doi.org/10.1080/00063659809461099

Terraube, J., and B. Arroyo. 2011. Factors influencing diet variation in a generalist predator across its range distribution. Biodiversity Conservation 20:2111-2131. http://dx.doi.org/10.1007/ s10531-011-0077-1

Terraube, J., B. Arroyo, M. Madders, and F. Mougeot. 2011. Diet specialisation and foraging efficiency under fluctuating vole abundance: a comparison between generalist and specialist avian predators. Oikos 120:234-244. http://dx.doi.org/10.1111/ j.1600-0706.2010.18554.x

Terry, A. M. R., T. M. Peake, and P. K. McGregor. 2005. The role of vocal individuality in conservation. Frontiers in Zoology 2:10. http://dx.doi.org/10.1186/1742-9994-2-10

Tutiš, V., J. Kralj, D. Radović, D. Ćiković, and S. Barišić. 2013. Red data book of birds of Croatia. Ministry of Environmental and Nature Protection and State Institute for Nature Protection, Zagreb, Croatia.

Underhill-Day, J. C. 1993. The foods and feeding rates of Montagu's Harriers Circus pygargus breeding in arable farmland. Bird Study 40:74-80. http://dx.doi.org/10.1080/00063659309477131

White, G. C., and K. P. Burnham. 1999. Program MARK: survival estimation from populations of marked animals. Bird Study 46 (Suppl.1):S120-S139. http://dx.doi.org/10.1080/00063659909477239 
White, T. C. R 2013. Experimental and observational evidence reveals that predators in natural environments do not regulate their prey: they are passengers, not drivers. Acta Oecologica 53:73-87. http://dx.doi.org/10.1016/j.actao.2013.09.007

Whittingham, M. J., and K. L. Evans. 2004. The effects of habitat structure on predation risk of birds in agricultural landscapes. Ibis 146(Suppl. 2):210-220. http://dx.doi.org/10.1111/

j.1474-919x.2004.00370.x 